\title{
Analysis of Residual Stress by the Hole-Drilling Method and Hardness in Dissimilar Joints of Austenitic Stainless Steel AISI 316L and Inconel 718 Alloy by Autogenous GTAW Process
}

\author{
Diogo de Amorim Gomes ${ }^{a}{ }^{\circledR}$, José Adilson Castro $^{a}{ }^{\mathbb{D}}$, Carlos Roberto Xavier $^{b}$, \\ Carlos Augusto Cardoso Lima ${ }^{a}$ (D) \\ ${ }^{a}$ Programa de Pós-graduação em Engenharia Metalúrgica, Universidade Federal Fluminense, Av. dos \\ Trabalhadores, Vila Santa Cecília, CEP 27255-125, Volta Redonda, RJ, Brasil \\ ${ }^{b}$ Centro Universitário de Volta Redonda, UniFOA, Av. Paulo Erlei Alves Abrantes, 1325, Três Poços, \\ CEP 27240-560, Volta Redonda, RJ, Brasil
}

Received: December 08, 2018; Revised: July 08, 2019; Accepted: October 16, 2019

\begin{abstract}
Stainless steel and nickel alloy have high corrosion resistance in high-temperature environments due to the high $\mathrm{Cr}$ content present in their chemical composition, being widely used in components of nuclear reactors, petrochemical industries, etc. Through proper processes and procedures, it becomes possible to join these alloys. However, this union can generate detrimental factors in its performance, among them, the residual stresses. In this work, the residual stresses generated by the autogenous GTAW process, due to different interpass temperatures on the weld bead geometry, were analyzed by the Hole-Drilling technique in dissimilar welding joints of stainless steel AISI 316L and Inconel 718 alloy. In addition, the Vickers microhardness measurements were carried out to evaluate the hardness profile in the cross section of the weld bead covering base metal (BM), heat affect zone (HAZ) and weld metal (WM). We found that in the interface region between BM and HAZ of each dissimilar joint metal, residual stresses increased above $300 \mathrm{MPa}$, while hardness increased above $160 \mathrm{HV}$.
\end{abstract}

Keywords: Stainless Steel AISI 316L, Inconel 718, Autogenous GTAW, Dissimilar Joints, Residual Stress, Hole-Drilling, Hardness.

\section{Introduction}

The world, after World War II, entered a stage of profound evolutions in the technological sector triggered mainly by the junction between scientific knowledge and the industrial production. The industrial process, based on knowledge and research, characterizes the so-called Third Industrial Revolution or Techno-Scientific Revolution, allowing the development of activities in the industry that apply cuttingedge technologies in the production stages, among them, in the production of metallic materials.

In this context, the austenitic stainless steel AISI $316 \mathrm{~L}$ and Inconel 718 alloy are widely used in nuclear power plants or conventional, chemical and petrochemical industries ${ }^{1}$. These alloys have high corrosion resistance in environments with high temperatures, due to the high content of $\mathrm{Cr}$ present in their chemical composition ${ }^{2,3}$.

Through a certain welding process, it is possible to join these alloys, generating the so-called dissimilar joints. Dissimilar joints are generally developed and produced within the highest quality standards ${ }^{4}$. However, some undesirable factors may arise, among them, the residual stresses, which are one of the main reasons to cause premature failure and defects in the parts, compromising their performance and even shortening the life of the component.

Residual stresses on welding occur due to non-uniform heating and cooling imposed by the thermal cycle ${ }^{5,6}$.
During welding, the region close to the weld pool is quite heated, while other regions of the base metal remain at much lower temperatures. The heated region tends to dilate but is restricted by regions with lower temperatures. As the weld metal cools, it tends to undergo thermal contraction but is also restricted by base metal that is at a different temperature, resulting in the development of elastic and plastic deformations in the material and frequently phase transformations which induces the local volume changes ${ }^{5}$.

The techniques of measuring residual stresses are divided according to the degree of damage to the component and its application. Several methods for the analysis of residual stresses have been developed by the industries, which allow knowing the state of these tensions in the material, avoiding catastrophic results. Among the methods used, we can mention: X-ray diffraction, neutron diffraction, synchrotron diffraction, ultrasonic, magnetic, sectioning, layer removal, and hole-drilling ${ }^{7,8,9}$.

Seeking innovation in the process and procedure, guaranteeing the requirements of safety, quality, environment and applicability of the welded component, we choose the hole-drilling method to study the behavior of residual stresses on dissimilar weld joints of AISI 316L and Inconel 718 alloy in the interface region between BM (Base Metal) and HAZ (Heat Affected Zone) of each dissimilar joint metal. In addition, the Vickers microhardness measurements were carried out to evaluate the hardness profile in the cross section of the weld bead covering BM, HAZ, WM (Weld Metal), both the methods in autogenous GTAW (Gas Tungsten Arc Welding) process conditions. 
The conditions were selected, aiming to prove the feasibility of the autogenous GTAW process, which allows suitable control of the welding pool.

\section{Materials and Methods}

The materials used as base metals in the present work were two plates of austenitic stainless steel AISI 316L and two plates of the Inconel 718 alloy, resulting in two specimens with dissimilar top joints, without chamfer, welded by the autogenous GTAW process, using $100 \%$ of argon as protection gas with a flow rate of $16 \mathrm{~L} / \mathrm{min}$ in order to stabilize the electric arc, all with the following dimensions: $60 \mathrm{~mm} \times 20 \mathrm{~mm} \times 5 \mathrm{~mm}$. Tables 1 and 2 show the bands of chemical composition and the mechanical properties of these plates.

The methodology used in this work was divided into three stages, according to Figure 1, which includes the welding processes and stresses measurements procedures.

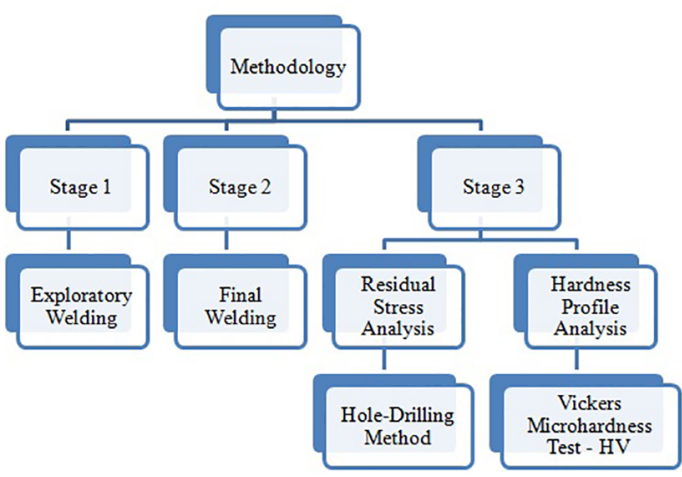

Figure 1. Flowchart of the stages performed in this work.

Stage 1 - Exploratory Welding: This stage aimed to explore the process to define the ideal welding parameters to obtain a quality joint, minimizing the occurrence of defects. The parameters to be considered were: welding speed $(\mathrm{mm} / \mathrm{s})$, gas flow rate $(\mathrm{L} / \mathrm{min})$, welding current (A), voltage (V), yield (\%) and polarity, capable of providing good arc stability and satisfactory surface finish.
From the welding of a dissimilar joint between super duplex steel 2304 and API X80 with dimensional characteristics similar to the specimen used in this work, it was possible to consider a maximum heat input of $0.68 \mathrm{~kJ} / \mathrm{mm}$.

Stage 2 - Final Welding: The final welding of the joints was performed based on the parameters raised in Step 1 - Exploratory Welding. Two specimens were prepared with dissimilar joints of austenitic stainless steel AISI 316L and Inconel 718 alloy by the autogenous GTAW process, varying the interpass temperature. A photograph of the general apparatus mounted to carry out the experimental runs is presented in Figure 2, which is similarly mounted for the previous study ${ }^{9,10}$.

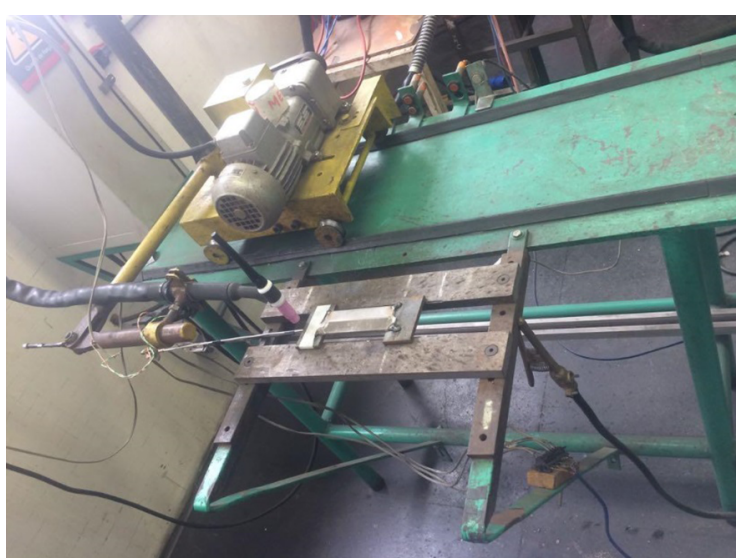

Figure 2. The positioning of the specimen and the contact tip.

The parameters monitored in this study, such as voltage (V), welding current $(A)$, welding speed $(\mathrm{mm} / \mathrm{s})$, heat input $(\mathrm{kJ} / \mathrm{mm})$, interlocking temperature $\left({ }^{\circ} \mathrm{C}\right)$ and number of steps applied on specimen 1 and 2 used in Stage 2 are indicated in Table $3^{9}$. As can be observed, the most important parameter was the interpass temperature, which is expected to be influential on the residual stresses distribution profile of the weld pieces.

Stage 3 - Residual Stress Analysis and Hardness Profile: Residual stress analyzes were performed using the Hole-Drilling Method and the hardness profile through the Vickers Microhardness Test.

Table 1. Chemical composition of the austenitic stainless steel AISI 316L and the Inconel 718 alloy used, according to the manufacturer's quality certificate

\begin{tabular}{lcccccccccccc}
\hline \multicolumn{1}{c}{ Plate } & $\begin{array}{c}\text { C (\% } \\
\text { weight) }\end{array}$ & $\begin{array}{c}\text { Mn (\% } \\
\text { weight) }\end{array}$ & $\begin{array}{c}\text { Si (\% } \\
\text { weight) }\end{array}$ & $\begin{array}{c}\text { P (\% } \\
\text { weight) }\end{array}$ & $\begin{array}{c}\text { S (\% } \\
\text { weight) }\end{array}$ & $\begin{array}{c}\text { Cr (\% } \\
\text { weight) }\end{array}$ & $\begin{array}{c}\text { Ni (\% } \\
\text { weight) }\end{array}$ & $\begin{array}{c}\text { Mo (\% } \\
\text { weight) }\end{array}$ & $\begin{array}{c}\text { Al (\% } \\
\text { weight) }\end{array}$ & $\begin{array}{c}\text { B (\% } \\
\text { weight) }\end{array}$ & $\begin{array}{c}\text { Cu (\% } \\
\text { weight) }\end{array}$ & $\begin{array}{c}\text { Fe (\% } \\
\text { weight) }\end{array}$ \\
\hline AISI 316L & 0.021 & 1.33 & 0.42 & 0.034 & 0.001 & 17.08 & 10.02 & 2.026 & 0.0036 & 0.0015 & 0.101 & 68.96 \\
INCONEL 718 & 0.021 & 0.02 & 0.03 & $<0.005$ & $<0.001$ & 18 & 52.4 & 2.95 & 0.44 & 0.003 & 0.01 & bal \\
\hline
\end{tabular}

Table 2. Mechanical properties of the austenitic stainless steel AISI 316L and the Inconel 718 alloy used according to the manufacturer's quality certificate.

\begin{tabular}{lcccc}
\hline \multicolumn{1}{c}{ Plate } & Yield Strength (MPa) & Ultimate Strength (MPa) & Elongation (\%) & Hardness (HRB) \\
\hline AISI 316L & 283 & 590 & 62 & 76.13 \\
INCONEL 718 & 861 & 1171 & 30 & 83 \\
\hline
\end{tabular}


Table 3. Parameters of the final welding used in Stage 2, considering the efficiency of the process equal to 0.8 .

\begin{tabular}{lcccccc}
\hline Specimen & Voltage (V) & Current (A) & Welding Speed (mm/s) & Heat Input (kJ/mm) & T INTERLOCKING $\left({ }^{\circ} \mathbf{C}\right)$ & Number of Steps \\
\hline 1 & 13.5 & 160 & 4.3 & 0.4 & 800 & 3 \\
2 & 13.5 & 160 & 4.3 & 0.4 & 600 & 3 \\
\hline
\end{tabular}

The analysis of the residual stresses by the HoleDrilling Method were performed in the two welded specimens from the autogenous GTAW process, where the test holes were rigorously performed with cutter inverted cone top tungsten carbide, with nominal diameter of $1.60 \mathrm{~mm}$, covering the interface region between $\mathrm{BM}$ and HAZ of each metal, at a distance of $1.5 \mathrm{~mm}$ from the WM, identified with the aid of optical microscope, totalizing in four tests. To analyze the results obtained in the hole-drilling test, the software EVAL, from the SINT manufacturer, was used in accordance with ASTM E837-08. The depth used in the hole-drilling was 0.925 $\mathrm{mm}$ for both metals, subdivided into ten steps, each step corresponding to $0.1 \mathrm{~mm}$. Due to the variation of the results obtained along with the depth used in the holes of the specimens, the non-uniform tensile method was used to evaluate the residual stresses according to ASTM E837 - Non Uniform Stress ${ }^{8}$. The equipment used was the Restan MTS 3000 model, through the High Speed Drilling Method according to ASTM E837-08, provided by SINT Technology, as shown in Figure 3.

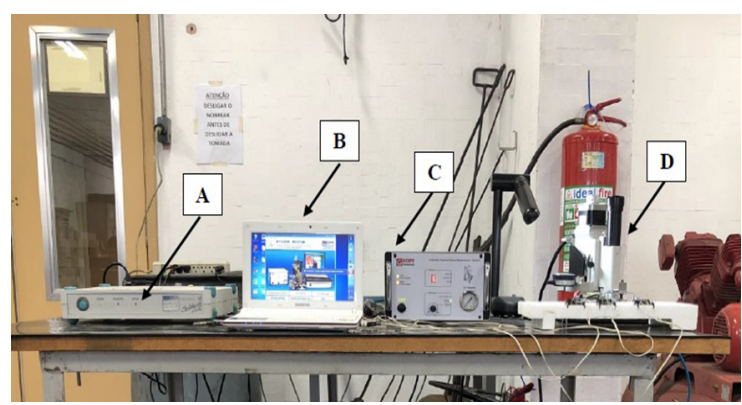

Figure 3. MTS3000 system for high-speed drilling. (A) Spider 8.30 Amplifier; (B) Control software (RSM) and post-processing (EVAL); (C) Electronic control unit; (D) Optical system and drilling system.

The two specimens from the autogenous GTAW process were submitted to the Vickers microhardness test, along the cross section to the weld bead covering $\mathrm{BM}, \mathrm{HAZ}$ and WM were plotted at a depth of $0.925 \mathrm{~mm}$ from the surface, evaluating the mechanical properties resulting from different welding tests, totalizing in two tests. Eighteen microhardness points were defined, 8 points spaced $0.25 \mathrm{~mm}$ in the transition region near HAZ between both metals and 10 points spaced $0.5 \mathrm{~mm}$ in the WM region. The Vickers microhardness equipment from the SHIMADZU-HMV manufacturer, where the applied load was $0.3 \mathrm{kgf}$ and the standard time of application of the load of 15 seconds, was used for the execution of the test in both specimens ${ }^{10,11}$.

\section{Results}

\subsection{Hole-drilling method}

The results of specimens 1 and 2, both in the Inconel 718 alloy and in the stainless steel AISI $316 \mathrm{~L}$, from experiments 1 and 2 , whose interlocking temperature were $800^{\circ} \mathrm{C}$ and $600^{\circ} \mathrm{C}$, it's detailed in the next sections.

\subsubsection{Specimen 1}

The results of specimen 1, both in the Inconel 718 alloy and in the stainless steel AISI $316 \mathrm{~L}$, from experiment 1 , whose interlocking temperature was $800^{\circ} \mathrm{C}$, it's detailed in the next sections.

Inconel 718: Next, we have the graph that shows the results obtained in specimen 1, contemplating the interface region between BM and HAZ of the Inconel 718 alloy. In this graph, we have the distribution of the minimum and maximum residual stress up to a depth of $0.925 \mathrm{~mm}$, as shown in Figure 4 .

AISI 316L: The following graph shows the results obtained in specimen 1, contemplating the interface region between BM and HAZ of stainless steel AISI 316L. In this graph, we have the distribution of the minimum and maximum residual stresses to a depth of $0.925 \mathrm{~mm}$, as shown in Figure 5 .

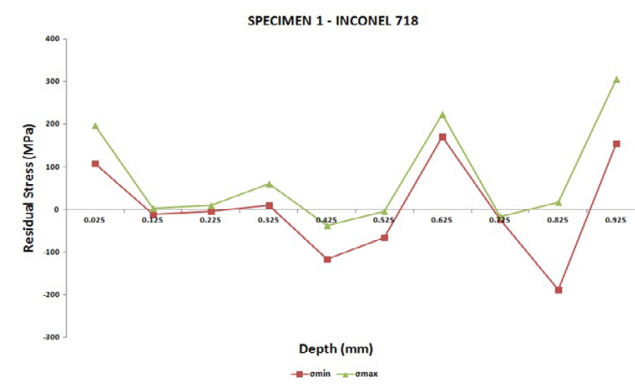

Figure 4. Distribution of the minimum and maximum residual stresses in specimen 1, contemplating the interface region between $\mathrm{BM}$ and $\mathrm{HAZ}$ of the Inconel 718 alloy

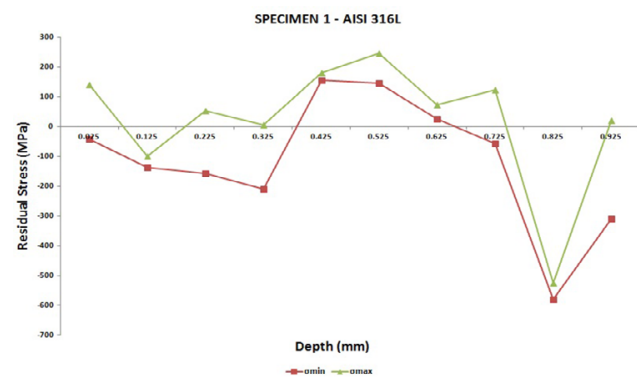

Figure 5. Distribution of the minimum and maximum residual stresses in specimen 1, contemplating the interface region between $\mathrm{BM}$ and HAZ of stainless steel AISI 316L. 


\subsubsection{Specimen 2}

The results of specimen 2, both in the Inconel 718 alloy and in the stainless steel AISI 316L, from experiment 2, whose interlocking temperature was $600^{\circ} \mathrm{C}$, it's detailed in the next sections.

Inconel 718: Next, we have the graph that shows the results obtained in specimen 2, contemplating the interface region between BM and HAZ of the Inconel 718 alloy. In this graph, we have the distribution of the minimum and maximum residual stress up to a depth of $0.925 \mathrm{~mm}$, as shown in Figure 6.

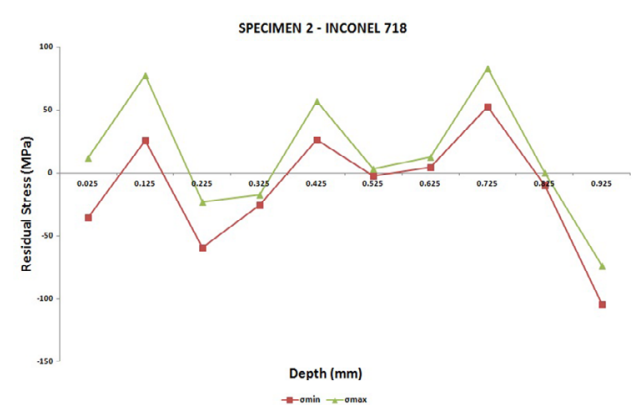

Figure 6. Distribution of the minimum and maximum residual stresses in specimen 2, contemplating the interface region between $\mathrm{BM}$ and HAZ of the Inconel 718 alloy.

AISI 316L: The following graph shows the results obtained in specimen 2, contemplating the interface region between BM and HAZ of stainless steel AISI 316L. In this graph, we have the distribution of the minimum and maximum residual stresses to a depth of $0.925 \mathrm{~mm}$, as shown in Figure 7.

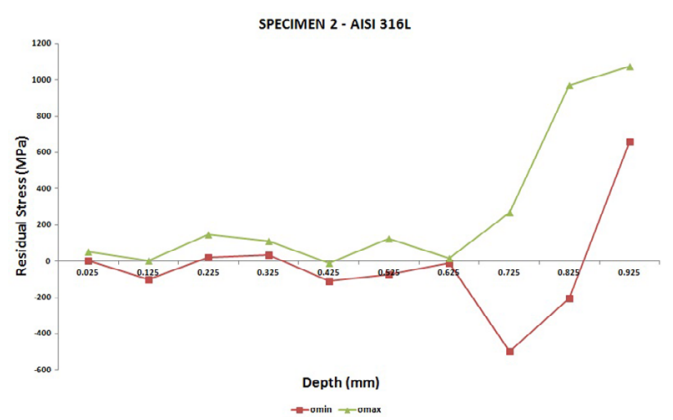

Figure 7. Distribution of the minimum and maximum residual stresses in specimen 2, contemplating the interface region between $\mathrm{BM}$ and HAZ of stainless steel AISI $316 \mathrm{~L}$

\subsection{Hardness profile}

The results of specimens 1 and 2, along the cross section to the weld bead covering BM, HAZ and WM, from experiments 1 and 2, whose interpass temperatures were $800^{\circ} \mathrm{C}$ and $600^{\circ} \mathrm{C}$, that is shown in Figure 8.

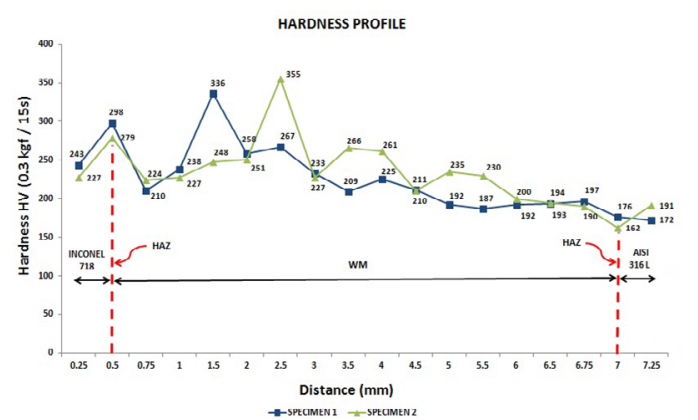

Figure 8. Hardness profile of specimens 1 and 2, along the cross section to the weld bead covering BM, HAZ and WM.

\section{Conclusion Remarks}

Based on the results obtained using the Hole-Drilling Method, it was found that specimens 1 and 2 showed a traction and compressive residual stress variation in the interface region between $\mathrm{BM}$ and $\mathrm{HAZ}^{9}$, both in the austenitic stainless steel AISI $316 \mathrm{~L}$ and in the Inconel 718 alloy, from the surface up to the depth of $0.925 \mathrm{~mm}$. The results obtained in the interface region between $\mathrm{BM}$ and $\mathrm{HAZ}$ of the Inconel 718 alloy presented values of stresses in acceptable levels, free of localized plastic deformations, in both specimens. Analyzing the results obtained in the interface region between BM and HAZ of stainless steel AISI $316 \mathrm{~L}$, values higher than $60 \%$ of the Yield Strength were observed in a depth between $0.725 \mathrm{~mm}$ and $0.925 \mathrm{~mm}$, could be associated to the loss in interpolation capacity and resolution of the data by virtue of the increase of the hole depth relative to the surface ${ }^{8}$. Making a comparison of the results of the maximum and minimum residual stresses, considering the region of the interface between BM and HAZ in the austenitic stainless steel AISI 316L along the depth, varying the interpass temperature, it was observed that the lower the interpass temperature in the larger sample will be the value of the residual stress in it, due to the longer time in the cooling cycle generating greater distortions in the crystalline structure of the material ${ }^{12}$. The results obtained in residual stress by the Hole-Drilling Method in the Inconel 718 alloy and the stainless steel AISI 316L were similar to those observed in the studies conducted by Mathieu et al. ${ }^{13}$.

The results obtained in the hardness profile were consistent, where higher hardness values were observed in the transition region of the Inconel 718 alloy and its respective HAZ compared to the transition region of stainless steel AISI 316L and its respective HAZ, wherein the transverse direction the welded joint the chemical composition of the Inconel 718 alloy is diluted in the $316 \mathrm{~L}$ stainless steel, resulting in a gradual decrease of the microhardness ${ }^{13,14}$. The same relation between interlocking temperature and microhardness was observed in studies conducted by Demarque $^{9}$ and Oliveira ${ }^{6}$. 
In this way, we can conclude that the interface region between BM and HAZ of the Inconel 718 alloy presented levels results in residual stress oscillating between 300 $\mathrm{MPa}$ and - $200 \mathrm{MPa}$, and hardness in the range of 290 $\mathrm{HV}$ more satisfactory compared to the interface region between BM and HAZ of the stainless steel AISI 316L, giving it better mechanical properties in the dissimilar joint welded by the autogenous GTAW process at interpasses temperatures of $800^{\circ} \mathrm{C}$ and $600^{\circ} \mathrm{C}$, respectively.

\section{References}

1. Campos WRC, Gomes FJO, Gonçalves TN, Soares BA. Microstructural Characterization of the Dissimilar Welding Austenitic Stainless Steel AISI 304 with Nickel Filler Metal Inconel 625. Tecnologia em Metalurgia, Materiais e Mineração. 2009;6(1):19-23.

2. Molak RM, Paradowski K, Brynk T, Ciupinski L, Pakiela Z, Kurzydlowski KJ. Measurement of mechanical properties in a 316L stainless steel welded joints. International Journal of Pressure Vessels and Piping. 2009;86:43-47.

3. Niang A, Viguier B, Lacaze J. Some features of anisothermal solidstate transformations in alloy 718. Materials Characterization. 2010;61(5):525-534.

4. Sireesha M, Albert SK, Sundaresan S. Thermal cycling of transition joints between modified $9 \mathrm{Cr}-1 \mathrm{Mo}$ steel and alloy 800 for steam generator application. International Journal of Pressure Vessels and Piping. 2002;79(12):819-27.

5. Hosford WF. Mechanical Behavior of Materials. Cambridge: Cambridge University Press; 2005.

6. Oliveira EM. Comportamento microestrutural da liga Inconel 718 em aplicações por soldagem $T I G$ [dissertation]. Rio de Janeiro (RJ): CEFET-RJ; 2011.
7. Rossini N, Dassisti M, Benyounis K, Olabi AG. Methods of Measuring Residual Stresses in Components. Materials and Design. 2012;35:572-588.

8. American Society for Testing Materials (ASTM). E837-08E2 Standard Test Method for Determining Residual Stresses by the Hole-Drilling Strain-Gage Method. West Conshohocken, PA: ASTM International; 2009.

9. Demarque R. Estudo da influência da corrente e da temperatura de interpasse sobre as transformações metalúrgicas de juntas dissimilares de aço inox AISI 316L e liga Inconel 718 pelo processo multipasse TIG autógeno [dissertation]. Volta Redonda (RJ): Federal Fluminense University; 2018.

10. Silva GC, Castro JA, Caldeira L, Lagares Junior MLL. Avaliação microestrutural e resistência à corrosão de uma junta dissimilar entre um aço de alta resistência e baixa liga e aço um inoxidável duplex. Soldagem \& Inspeção. 2019;24:e2404.

11. Sousa DA. Determinação de tensões residuais em materiais metálicos por meio de ensaio de dureza [dissertation]. São João Del-Rei (MG): Federal University of São João del Rei; 2012.

12. Lu J. Handbook of Measurement of Residual Stress. Upper Saddle River, NJ: Prentice Hall; 1996.

13. Girinon M, Dumont F, Valiorgue F, Rech J, Feulvarch E, Lefebvre $F$, et al. Influence of lubrication modes on residual stresses generation in drilling of $316 \mathrm{~L}, 15-5 \mathrm{PH}$ and Inconel 718 alloys. Procedia CIRP. 2018;71:41-46.

14. Peres RA. Análise de tensões residuais através do método do furo cego em blanks de aço ARBL microligados ao $\mathrm{Nb}$ soldados pelo processo laser a gás de $\mathrm{CO}_{2}$ [dissertation]. Volta Redonda (RJ): Federal Fluminense University; 2014. 